\title{
Post pollination events in a self-sterile hexaploid monoembryonic lineage of Handroanthus serratifolius (Vahl) S. Grose (Bignoniaceae)
}

\author{
Mariana Ferreira Alves ${ }^{1} \odot$, Nelson Sabino Bittencourt Júnior ${ }^{2} \odot$, Paulo Eugênio Oliveira ${ }^{1} \odot$ \\ and Diana Salles Sampaio ${ }^{1 *}$
}

Received: April 15, 2019

Accepted: June 28, 2019

\begin{abstract}
In diploid late-acting self-incompatible (LSI) species of Bignoniaceae, self-pollinated pistils show a marked delay in ovule penetration by pollen tubes, followed by delayed, but otherwise normal, initial stages of endosperm development and subsequent pistil abscission. Most polyploid species of Bignoniaceae are apomictic and set selfed fruits with viable polyembryonic seeds carrying adventitious embryos. Handroanthus serratifolius is a polyploid species with sporophytic apomictic individuals that produce polyembryonic seeds after either self- or cross-pollination, and other LSI individuals that produce exclusively monoembryionic seeds. Our aim was to determine whether self-sterility events in the latter are similar to those observed in other diploid LSI species of Bignoniaceae. No conspicuous differences in the progress of ovule penetration, fertilization and early stages of endosperm development were observed between selfed and crossed pistils, which contrasts with the marked delay observed in these events after self-pollination in diploid LSI species of the family. Adventitious embryo precursor cells (AEPs) were observed in some ovules, but they apparently do not develop into embryos. We believe that the AEPs in these plants represent a 'potential' for sporophytic apomixis, which would explain the similar behaviour of post-pollination events in selfed vs. crossed pistils despite their inability to set fruits after selfing.
\end{abstract}

Keywords: adventitious embryo precursor cells, Handroanthus serratifolius, polyploidy, self-sterility, Tabebuia serratifolia

\section{Introduction}

Polyploidization has been recognized as a source of novelty and diversification for the angiosperms (Ramsey \& Schemske 1998; Soltis \& Soltis 2016). It is associated with changes in breeding systems and considered a trigger to selffertility and apomixis, apparently favouring reproductive assurance in individuals with recent polyploidization (Pannell et al. 2004; Barringer 2007). Although polyploidy does not always lead to the breakdown of self-incompatibility (Mable 2004), it has certainly been associated with the breakdown of gametophytic self-incompatibility (GSI) in some species (Nettancourt 1997; Levin 2002; Pannell et al. 2004; Husband et al. 2008) and emergence of gametophytic apomixis (Whitton et al. 2008).

Most Bignoniaceae species present $2 \mathrm{n}=40$ chromosomes, the diploid number for the family (Goldblatt \& Gentry 1979; Piazzano et al. 2015; Cordeiro et al. 2017). Of these species, those that have been studied for the breeding system mostly show late-acting self-incompatibility (LSI), and no conventional gametophytic or sporophytic SI has been reported (Gibbs \& Bianchi 1993; 1999; Bittencourt et al. 2003; 2011; Bittencourt \& Semir 2004; 2005; 2006;

1 Instituto de Biologia, Universidade Federal de Uberlândia, 38400-902, Uberlândia, MG, Brazil

2 Departamento de Zoologia e Botânica, Instituto de Biociências, Humanidades e Ciências Exatas, Universidade Estadual Paulista,

15054-000, São José do Rio Preto, SP, Brazil

* Corresponding author: sampaiodsbot@yahoo.com.br 
Gandolphi \& Bittencourt 2010; Gibbs 2014; Bittencourt 2017). The LSI mechanism in Bignoniaceae species is characterized by pollen tube growth down to the ovary in self-pollinated pistils. These pollen tubes penetrate and fertilize most ovules before the selfed pistils abscise (Seavey \& Bawa 1986; Sage et al. 1994; Gibbs 2014; Bittencourt 2017).

Studies with polyploid Bignoniaceae (e.g. Handroanthus chrysotrichus, H. ochraceus and Anemopaegma acutifolium) and Malvaceae-Bombacoideae (e.g. Eriotheca pubescens) indicate that suppression of self-pollinated pistil abscission may result from the rapid development of adventitious embryos in selfed ovule/seeds in species that show sporophytic apomixis (Oliveira et. al. 1992; Costa et al. 2004; Bittencourt \& Moraes 2010; Sampaio et al. 2013a). Early adventitious embryo initiation in these apomictic species could prevent selfed pistils from being aborted even if the zygote or sexual embryo fail to survive, a phenomenon that has been reported as apomixis-related pseudo self-compatibility (Bittencourt \& Moraes 2010; Sampaio et al. 2013a). This term (apomixis-related pseudo self-compatibility) is used when the genetic control of self-incompatibility is maintained, but self-pollinated pistils set fruits (Hörandl 2010). In the case of Bignoniaceae it occurs due the delay of self pistil rejection in LSI species, allowing endosperm formation and the development of adventitious embryos by pseudogamy, which is considered a novel type of pseudo self-compatibility (Bittencourt \& Moraes 2010; Sampaio et al. 2013a) and seems to be also the case in MalvaceaeBombacoideae apomictic sporophytic species (Oliveira et. al. 1992; Mendes-Rodrigues et al. 2019). Among polyploid species of Bignoniaceae, only Pyrostegia venusta is known to be self-fertile, monoembryonic and apparently nonapomictic (Joshi \& Hardas 1956; Gobatto Rodrigues \& Stort 1992; Sampaio 2010; Cordeiro et al. 2017).

Handroanthus serratifolius is mainly polyploid, $2 n=40,80$ and 120 chromosomes were found (Simmonds 1954; Alves et al. 2013; Collevatti \& Dornelas 2016), and presents both polyembryonic and monoembryonic hexaploid populations (Mendes-Rodrigues et al. 2012; Alves et al. 2013). As in other Handroanthus polyploid species, polyembryonic populations of $H$. serratifolius present the above-mentioned apomixisrelated pseudo self-compatibility (Alves et al. 2016), while monoembryonic populations are reported to be self-sterile (Alves et al. 2013). There are histological evidences of sexual embryo development concomitantly to adventitious embryos in self-fertilized seeds of polyembryonic populations (Alves et al. 2016), even though this coexistence was not evaluated by studies employing molecular markers.

Post-pollination events in most LSI Bignoniaceae studied to date, characterized by a marked delay in ovule penetration, fertilization and endosperm initiation in selfed pistils prior to their abscission (Bittencourt et al. 2003; 2011; Bittencourt \& Semir 2004; 2005; 2006; Gandolphi $\&$ Bittencourt 2010; Gibbs 2014; Bittencourt 2017). On the other hand, in the polyploid sporophytic apomictic Bignoniaceae $H$. chrysotrichus and A. acutifolium, only a slight delay in endosperm initiation in self-pollinated pistils has been observed, which does not result in their abortion presumably due to adventitious embryo development (Bittencourt \& Moraes 2010; Sampaio et al. 2013a).

The present study aimed to determine whether the self-sterility mechanisms in the hexaploid monoembryonic $H$. serratifolius are similar to those observed in the diploid monoembryonic Handroanthus and other Bignoniaceae species studied so far. Although the effects of polyploidy in self-sterile species in the family is unknown, we presume that endosperm initiation would be markedly delayed in self-pollinated pistils in comparison to cross-pollinated ones as observed in diploid LSI species of Bignoniaceae.

\section{Materials and methods}

\section{Species and studied sites}

Handroanthus serratifolius (Vahl.) S. Grose is an up to $30 \mathrm{~m}$ tall tree; the flower shows an yellow tubularinfundibuliform corolla; the fruit is a linear, inconspicuously lepidote capsule with longitudinal grooves and many extrafloral nectaries, which takes about 30 days to reach maturity (Gentry 1992; Alves et al. 2013). The species is deciduous, showing a massive flowering during the dry season, which has been recognized as a "big bang" type flowering phenology (sensu Gentry 1974). The species is widely distributed in South America and the state of São Paulo (Brazil) is its southernmost occurrence area (Gentry 1992). Investigations of ploidy and breeding system were restricted to Goiás, Minas Gerais and São Paulo States (Brazil), where only tetraploid and hexaploid populations were found, with polyembryonic populations (apomictic) occurring in Goiás and the Triângulo Mineiro in Minas Gerais State, and monoembryonic populations (sexual) also in the Triângulo Mineiro and at the center of Minas Gerais State (Sampaio 2010; Mendes-Rodrigues et al. 2012).

Studies on monoembryonic hexaploid trees were conducted in 2010 with three cultivated individuals located in Uberlândia ( $18^{\circ} 53^{\prime} 15.03^{\prime \prime S} 48^{\circ} 15^{\prime} 37.35^{\prime \prime} \mathrm{W}$ ), and also in two individuals located in Uberaba (19.39'51.27"S $47^{\circ} 58^{\prime} 05.40^{\prime \prime} \mathrm{W}$ ), Minas Gerais, Brazil (all five trees were the same used in the study by Alves et al. 2013). Other studies with monoembryonic hexaploid individuals were conducted in 2013 with three cultivated individuals also located in Uberlândia ( $18^{\circ} 58^{\prime} 25.11^{\prime \prime} \mathrm{S} 48^{\circ} 17^{\prime} 26.10^{\prime \prime} \mathrm{W}$; and $\left.18^{\circ} 55^{\prime} 01.09^{\prime \prime} \mathrm{S} 48^{\circ} 14^{\prime} 58.13^{\prime \prime} \mathrm{W}\right)$. The monoembryony and ploidy of the individuals studied in 2013 had been previously verified (Alves et al. 2013). Vouchers were deposited in Herbarium Uberlandense (HUFU), Uberlândia, Minas Gerais, Brazil, under the following registration numbers: Uberaba - HUFU 60075; Uberlândia - HUFU 48932, 5286, 52590 and 52591. 


\section{Mariana Ferreira Alves, Nelson Sabino Bittencourt Júnior, Paulo Eugênio Oliveira and Diana Salles Sampaio}

\section{Experimental pollinations}

Experimental pollinations were carried out to obtain pistils for histological analysis of ovule penetration, fertilization and initial endosperm development. Flower buds were bagged with nylon mesh to avoid contact with possible floral visitors. Hand self- and cross-pollinations were done in previously emasculated first-day flowers. In self-pollinations, we used the pollen grains of the same flower, and in cross-pollinations in the same locality (we did not cross trees from different localities) we used pollen from individuals at least $10 \mathrm{~m}$ distant.

\section{Histological analysis}

To investigate the post-pollination events in selfsterile monoembryonic individuals, four pistils from self-pollinations and four from cross-pollinations were collected 24, 48, 72, 96 and $120 \mathrm{~h}$ after pollination from two individuals of Uberlândia and the two individuals of Uberaba, except for the 72-hour interval after selfpollination for which three pistils were used. In order to analyse later stages of seed development, fruits from natural pollinations at different developmental stages $(2-15 \mathrm{~cm}$ long) were also collected from the same two individuals in Uberlândia.

Prior to fixation in $1 \%$ glutaraldehyde and $4 \%$ formaldehyde solution in sodium phosphate buffer $0.1 \mathrm{M}$, pH 7.2 (McDowell \& Trump 1976), pistil and fruit walls were removed using a scalpel and tweezers under a stereomicroscope Olympus SZX12. The fixed materials were dehydrated in an ethanol series and passed through a series ethanol: chloroform (3:1, 1:1, 3:1) to remove epicuticular waxes. Embedding was carried out with hydroxyethylmethacrylate (Gerrits \& Smid 1983) and serial sections from 3 - $5 \mu \mathrm{m}$ thick were obtained using a rotary microtome Leica RM2135 with an 8-mm wide Leica glass knife. The sections were stained with Toluidine Blue O $0.05 \%$ in sodium benzoate buffer, $\mathrm{pH} 4.4$ (Feder \& O' Brien 1968) and slides were sealed with Permount ${ }^{\circledR}$. Analyses and photomicrographs were made using an Olympus BX51 light microscope equipped with a digital camera (Olympus DP70).

Ovules with a deeply stained penetrated synergid and an evident cytoplasmic loop were considered fertilized. A nuclear DNA quantitative study with Handroanthus impetiginosus by Bittencourt (2017) has confirmed this presumption, and supports the comparison of penetrated and fertilized ovules among treatments.

\section{Statistical analysis}

The chi-square test was used to compare the number of penetrated and fertilized ovules, and ovules with endosperm at different stages of development between self- and cross-pollination treatments with the statistical package BioEstat (Ayres et al. 2007). Please note that sample sizes were constrained by the access to previously ploidyprofiled trees and time consuming histological procedures. We used treated flowers from the different individuals to avoid maternal effect and reduce pseudo-replication, but the flowers (pistils) were used as sample unities. Despite the use of conservative statistical tests, results should be taken cautiously.

\section{Results}

Monoembryonic hexaploid individuals of $H$. serratifolius present a Polygonum megagametophyte (Fig. 1A). Regardless of the type of pollination, pollen tubes arrived in the ovary and ovule penetration ensued with the discharge of pollen tube content into one of the synergids, which stained densely (Fig. 1B) and presented a characteristic cytoplasmic 'loop' around the chalazal end of the egg cell (not shown), and these ovules were considered fertilized. In this phase the polar nuclei were in process of fusion (Fig. 1B). Some ovules in which pollen tube had penetrated but not yet discharged its cytoplasmic content into a synergid were also observed, and considered penetrated but not fertilized. Two of the 874 fertilized ovules analyzed presented both synergids penetrated by pollen tubes (Fig. 1C).

The pattern of endosperm initial development did not differ among pollination treatments. After fusion, the primary endosperm cell underwent karyokinesis (Fig. 1D) followed by cytokinesis. This first division was transverse and originated two cells, one in the micropylar area and the other in the chalazal area (Fig. 1E). The second division of the endosperm was longitudinal in both cells, giving rise to a four-celled endosperm (Fig. 1F). However, this cycle of divisions occurred asynchronously with the chalazal one dividing first and resulting in an intermediate threecelled endosperm stage. The third cycle of divisions of the endosperm was transverse and occurred only in the micropylar pair of cells, originating a six-celled endosperm (not shown). The next endosperm divisions, which were observed in the middle cells $72 \mathrm{~h}$ after pollination onwards (Tab. 1), were always transverse, originating a biseriate endosperm (Fig. 1G, H). From the stage of 16-celled endosperm onwards, the two chalazal cells showed a dense cytoplasmic staining and were identified as the endosperm chalazal haustorium (Fig. 1H).

Fertilization and endosperm initiation were observed in ovules of both crossed and selfed pistils (Tab. 1). A larger number of fertilized ovules (relative to unfertilized ones) was found in self-pollinated pistils at the $24 \mathrm{~h}$ interval $\left(\chi^{2}=\right.$ $4.56, p=0.0322$ ), but no significant difference was verified between the two treatments with regard to the number of fertilized ovules showing a developing (2-celled) endosperm $\left(\chi^{2}=0.98, p=0.3222\right)$. At $48 \mathrm{~h}$ after pollination, crosspollinated pistils presented more fertilized ovules or ovules in later stages of endosperm division than self-pollinated 

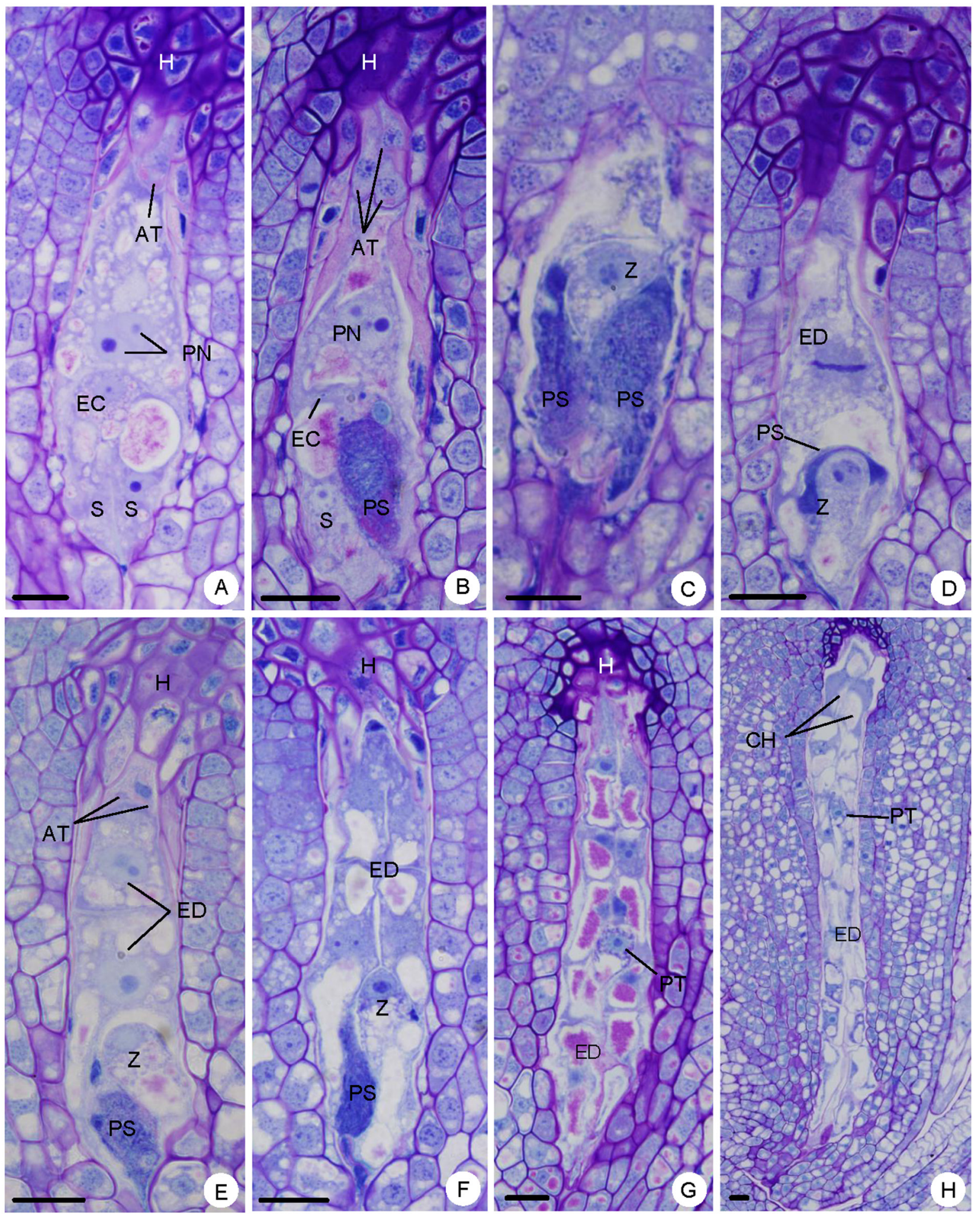

Figure 1. Longitudinal sections of ovules and young seeds of Handroanthus serratifolius, all with the micropylar end at bottom: A. Polygonum-type megagametophyte $24 \mathrm{~h}$ after cross-pollination; B. Penetrated and non-penetrated synergid, 24h after self-pollination; C Two penetrated synergids and zygote $48 \mathrm{~h}$ cross-pollination; D. Cytoplasmatic loop of the penetrated synergid around the chalazal pole of the zygote, and primary endosperm cell with a metaphase plate during mitosis, $48 \mathrm{~h}$ after cross-pollination; E Penetrated synergid, zygote and a two-celled endosperm, $48 \mathrm{~h}$ after cross-pollination; F. Penetrated synergid, zygote and a four celled endosperm, $72 \mathrm{~h}$ after cross-pollination; G. Proembryonal tube and ten-celled endosperm, $96 \mathrm{~h}$ after cross-pollination; H. Proembryonal tube and 14-celled endosperm $120 \mathrm{~h}$ after self-pollination. AT: antipodals; $\mathrm{CH}$ : chalazal haustorium; EC: egg cell; ED: endosperm; H: hypostasis; PN: polar nuclei; PS: penetrated synergid; PT: proembryonal tube; S: synergid; Z: zygote. Scale bars: $20 \mu \mathrm{m}$. 


\section{Mariana Ferreira Alves, Nelson Sabino Bittencourt Júnior, Paulo Eugênio Oliveira and Diana Salles Sampaio}

Table 1. Post-pollination events in ovules 24-120 hours after self- versus cross-pollinations in monoembryonic individuals of Handroanthus serratifolius (Vahl) S. Grose from Uberlândia and Uberaba, MG, Brazil. Each column pools observations from 3-4 pistils sampled at random from each treatment. $\mathrm{N}$ Pen = non-penetrated; Pen = penetrated by pollen tubes; Fer = fertilized; $\mathrm{E}=$ with a developing endosperm (the following number indicates the number of cells in the endosperm body). Self=self-pollination; Cross=cross-pollination.

\begin{tabular}{|c|c|c|c|c|c|c|c|c|c|c|}
\hline \multirow{2}{*}{ Stages } & \multicolumn{2}{|c|}{24 hours (\%) } & \multicolumn{2}{|c|}{48 hours (\%) } & \multicolumn{2}{|c|}{72 hours (\%) } & \multicolumn{2}{|c|}{96 hours (\%) } & \multicolumn{2}{|c|}{120 hours (\%) } \\
\hline & Self & Cross & Self & Cross & Self & Cross & Self & Cross & Self & Cross \\
\hline N Pen & 258(91.5\%) & $246(95.7 \%)$ & $173(69.2 \%)$ & $110(47.8 \%)$ & $103(42.4 \%)$ & 140(59.3\%) & 141(59.0\%) & $54(31.0 \%)$ & $51(39.5 \%)$ & 148(55.4\%) \\
\hline Pen & $2(0.7 \%)$ & $2(0.8 \%)$ & $1(0.4 \%)$ & 0 & 0 & $2(0.8 \%)$ & 2 (0.8\%) & 0 & 0 & 0 \\
\hline Fer & $20(7.1 \%)$ & $7(2.7 \%)$ & $16(6.4 \%)$ & 77 (33.5\%) & $11(4.5 \%)$ & $5(2.1 \%)$ & $12(5.0 \%)$ & $4(2.3 \%)$ & $6(4.7 \%)$ & $9(3.4 \%)$ \\
\hline E2 & $2(0.7 \%)$ & $2(0.8 \%)$ & 30 (12\%) & 35 (15.2\%) & $20(8.2 \%)$ & $10(4.2 \%)$ & $11(4.6 \%)$ & 0 & $3(2.3 \%)$ & 7 (2.6\%) \\
\hline E3 & 0 & 0 & $13(5.2 \%)$ & $2(0.9 \%)$ & $10(4.1 \%)$ & $7(3.0 \%)$ & $10(4.2 \%)$ & $6(3.4 \%)$ & $1(0.8 \%)$ & 12 (4.5\%) \\
\hline E4 & 0 & 0 & $17(6.8 \%)$ & $6(2.6 \%)$ & $33(13.6 \%)$ & 22 (9.3\%) & $19(7.9 \%)$ & $16(9.2 \%)$ & $3(2.3 \%)$ & $10(3.7 \%)$ \\
\hline E5 & 0 & 0 & 0 & 0 & $19(7.8 \%)$ & $11(4.7 \%)$ & $3(1.3 \%)$ & $7(4.1 \%)$ & $1(0.8 \%)$ & $11(4.1 \%)$ \\
\hline E6 & 0 & 0 & 0 & 0 & 27 (11.1\%) & 21 (8.9\%) & $16(6.7 \%)$ & $26(14.9 \%)$ & $5(3.8 \%)$ & $17(6.4 \%)$ \\
\hline E7 & 0 & 0 & 0 & 0 & $14(5.8 \%)$ & 9 (3.8\%) & $1(0.4 \%)$ & $9(5.2 \%)$ & 2 (1.6\%) & $2(0.7 \%)$ \\
\hline E8 & 0 & 0 & 0 & 0 & $6(2.5 \%)$ & $8(3.4 \%)$ & $17(7.1 \%)$ & $33(19.0 \%)$ & 7 (5.4\%) & 7 (2.6\%) \\
\hline E9 & 0 & 0 & 0 & 0 & 0 & 0 & $2(0.8 \%)$ & $6(3.4 \%)$ & $4(3.1 \%)$ & 5 (1.9\%) \\
\hline E10 & 0 & 0 & 0 & 0 & 0 & $1(0.4 \%)$ & 4 (1.7\%) & $13(7.5 \%)$ & 7 (5.4\%) & $15(5.6 \%)$ \\
\hline E11 & 0 & 0 & 0 & 0 & 0 & 0 & $1(0.4 \%)$ & 0 & $5(3.8 \%)$ & $2(0.8 \%)$ \\
\hline E12 & 0 & 0 & 0 & 0 & 0 & 0 & 0 & 0 & $11(8.5 \%)$ & $11(4.1 \%)$ \\
\hline E13 & 0 & 0 & 0 & 0 & 0 & 0 & 0 & 0 & 2 (1.6\%) & $1(0.4 \%)$ \\
\hline E14 & 0 & 0 & 0 & 0 & 0 & 0 & 0 & 0 & $5(3.9 \%)$ & $8(3.0 \%)$ \\
\hline E15 & 0 & 0 & 0 & 0 & 0 & 0 & 0 & 0 & $1(0.8 \%)$ & $1(0.4 \%)$ \\
\hline E16 & 0 & 0 & 0 & 0 & 0 & 0 & 0 & 0 & $3(2.3 \%)$ & 0 \\
\hline E17 & 0 & 0 & 0 & 0 & 0 & 0 & 0 & 0 & 2 (1.6\%) & 0 \\
\hline E18 & 0 & 0 & 0 & 0 & 0 & 0 & 0 & 0 & 5 (3.8\%) & $1(0.4 \%)$ \\
\hline E20 & 0 & 0 & 0 & 0 & 0 & 0 & 0 & 0 & 2 (1.6\%) & 0 \\
\hline E21 & 0 & 0 & 0 & 0 & 0 & 0 & 0 & 0 & 2 (1.6\%) & 0 \\
\hline E24 & 0 & 0 & 0 & 0 & 0 & 0 & 0 & 0 & $1(0.8 \%)$ & 0 \\
\hline Total & 282 & 257 & 250 & 230 & 243 & 236 & 239 & 174 & 129 & 267 \\
\hline
\end{tabular}

pistils $\left(\chi^{2}=22.616, \mathrm{p}<0.0001\right)$, although fertilized ovules in self-pollinated pistils presented more ovules with four celled endosperms (Tab. 1, Fig. 2). At $96 \mathrm{~h}$ after pollination, cross-pollinated pistils showed $30 \%$ of their ovules with eight or more endosperm cells, while only $10 \%$ of ovules in self-pollinated pistils appeared in this condition $\left(\chi^{2}=5.46\right.$, $\mathrm{p}=0.0194)$ (Tab. 1, Fig. 2). At $120 \mathrm{~h}$ after pollination, selfpollinated pistils presented more ovules with 12 or more cells in the endosperm than cross-pollinated pistils $\left(\chi^{2}=\right.$ 15.13 , p < 0.0001) (Tab. 1, Fig. 2), but 104 of the 129 selfed ovules analysed at this time interval showed endosperm with degenerating cells, evidenced by a reduced/scant cytoplasm and collapsing nuclei (Fig. 3A, B). Note that despite a normal succession of rise and fall cycles in the proportion of ovules containing a progressively greater numbers of cells in the endosperm, their development tended to be more vigorous in cross-pollinated pistils, with the selfed ones showing a longer turn-over among endosperm stages (stretching of the curves to the right in Fig. 2). However, except for the degenerative signs in ovules of the $120 \mathrm{~h}$ selfed pistils, the qualitative cytological features of the endosperm in its first developmental steps were the same in both selfed and crossed pistils.

Very rarely (only 10 out of 2.307 ovules analysed) somatic hypostase cells extending into the interior of the megagameophyte/endosperm were observed in both selfed and crossed ovules in all stages analysed (Fig. 3C, D). Five ovules with these cells were from self-pollinated pistils, three of which from unfertilized ovules, and the other five ovules were from cross pollinated pistils, three of which also found in unfertilized ovules (Fig. 3C). These cells were identical to the adventitious embryo precursors cells (AEP) found in apomictic H. serratifolius (Alves et al. 2016).

All 47 seeds from natural pollinated fruits analyzed in the various stages of development showed the presence of only one sexual embryo per seed (Fig. 3E-H). Initiating seeds in young fruits, between $24-120$ hours after cross and self-pollination, always showed a zygotic proembryonal tube in addition to the biseriate endosperm (Fig. 1H). In fruits longer than $2 \mathrm{~cm}$, the endosperm was multilayered, and the sexual embryo was present, in cordiform and torpedo stages (Fig. 3E-H).

\section{Discussion}

Handroanthus serratifolius showed a cellular endosperm with a two-celled chalazal haustorium differentiating in the early stages of seed development, as observed in other Handroanthus species (Sampaio et al. 2007), which corresponds to the Catalpa-type endosperm as described by Mauritzon (1935). The qualitative features of fertilization 
and endosperm initial development in monoembryonic individuals of $H$. serratifolius were similar between self- and cross-pollinated pistils, and were the same as those observed in polyembryonic individuals of this species (Alves et al. 2016). Indeed, these features were equal to those reported for several sexual bignoniaceous species with LSI (Govindu 1950; Bittencourt et al. 2003; 2011; Bittencourt \& Semir 2005; 2006; Sampaio et al. 2007; Gandolphi \& Bittencourt 2010). These similarities indicate that polyploidy did not affect fertilization or major early endosperm development in Bignoniaceae, but induce adventitious embryo precursor cells initiation in somatic tissues of the studied species (Costa et al. 2004; Bittencourt \& Moraes 2010; Sampaio et al. 2013b).

The analysis of post-pollination events indicated only slight differences between fertilized ovules in selfed and crossed pistils with regard to the quantitative progress of
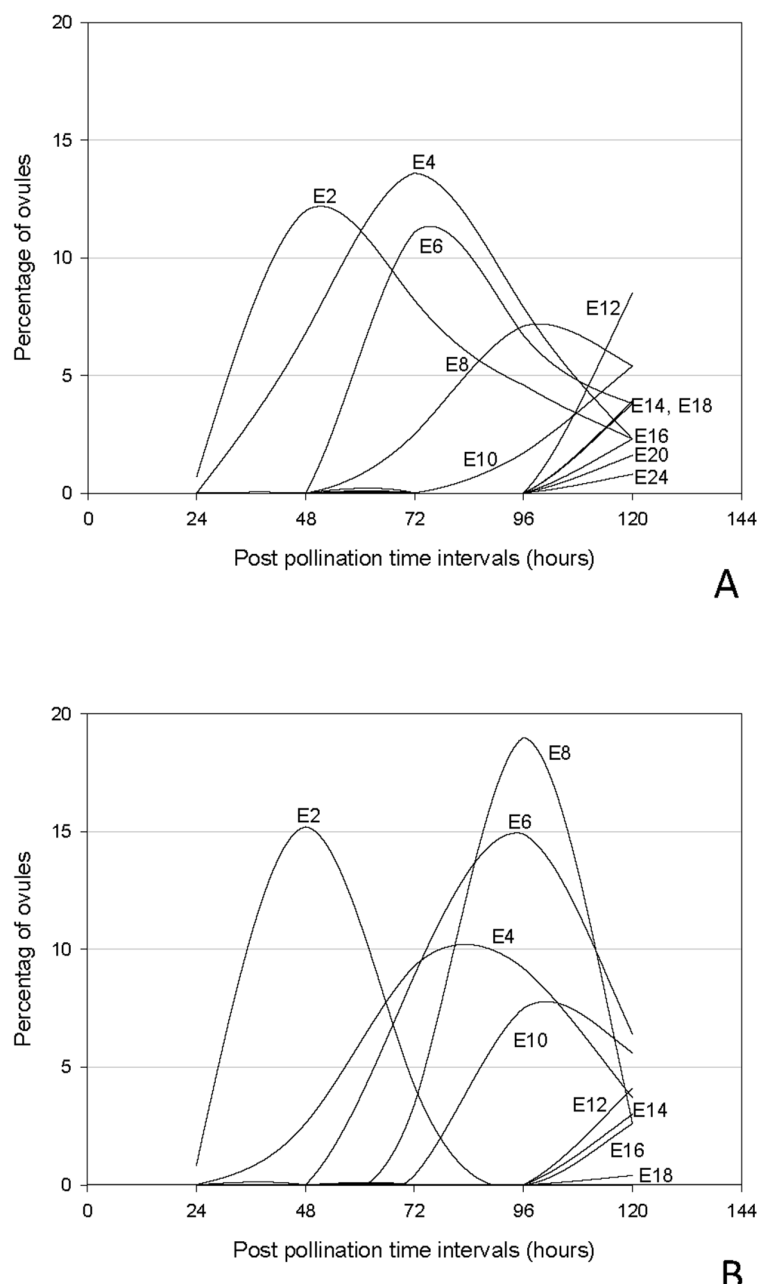

Figure 2. Percentage of ovules with endosperm in progressive developmental stages analysed in five post-pollination time intervals in Handroanthus serratifolius: A. Ovules from pistils of hand self-pollinations; B. Ovules from pistils of hand crosspollinations. E with the following number indicates the number of cells in the endosperm body. endosperm development up to the abscission stage in the former. In addition, there was no sign of malformations in selfed proembryonal tubes and/or endosperm, which accords with observations in other bignoniaceous species (Bittencourt \& Moraes 2010; Sampaio et al. 2013b). This supports the view that failure to set fruits following selfing is due to an LSI mechanism rather than the action of early acting recessive alleles, since in the latter case embryo or endosperm malfunctions would be expected (Bittencourt et al. 2003; Gibbs 2014).

The fact that only at 48 and $96 \mathrm{~h}$ after pollination crosspollinated pistils showed endosperms with more cells than self-pollinated ones contrasts with a marked delay at $24 \mathrm{~h}-72 \mathrm{~h}$ intervals reported for ovule penetration and fertilization, as well as initial endosperm development, in selfed vs. crossed pistils in various diploid LSI species (Bittencourt et al. 2003; 2011; Bittencourt \& Semir 2004; 2005; 2006; Gandolphi \& Bittencourt 2010; Gibbs 2014; Bittencourt 2017). In addition, the presence of AEPs, although in low frequency $(0.43 \%$ here vs. $2.5 \%$ in ovules of apomictic individuals; Alves et al. 2016), was a distinct feature of the studied individuals that has not been observed in self-sterile Bignoniaceae studied to date. On the other hand, they were identical to the AEPs found in other sporophytic apomictic Bignoniaceae (Costa et al. 2004; Bittencourt \& Moraes 2010; Sampaio et al. 2013b).

A similar non-expressive difference between crossed and selfed pistils in the progress of endosperm initiation accompanied by AEP formation have been reported in some tetraploid apomictic and polyembryonic bignoniaceous species, such as $H$. chrysotrichus (Bittencourt \& Morais 2010) and A. acutifolium (Sampaio et al. 2013a). In $H$. chrysotrichus, self-pollinated pistils show more ovules fertilized or with developing endosperms than crossed at $24 \mathrm{~h}$ after pollination, and with a greater number of endosperm cells $48 \mathrm{~h}$ after pollination. However, this situation changes at 72,96 and $120 \mathrm{~h}$ after pollination, with cross-pollinated pistils with a greater number of endosperm cells than selfed pistils (Bittencourt \& Morais 2010). In A. acutifolium, the endosperm in fertilized ovules of cross-pollinated pistils developed faster than those in selfed ones, although significant differences were observed only at $96 \mathrm{~h}$ after pollination (Sampaio et al. 2013a). In both species AEPs were verified in ovules of selfed and crossed pistils, as well as in unpollinated ones, although the effective conversion of these AEPs in adventitious embryos required pollination and fertilization (Bittencourt \& Morais 2010; Sampaio et al. 2013a; b). In the presently studied monoembrionic $H$. serratifolius, not only the observed post-pollination events invariably were followed by selfed pistil abscission a few days after pollination, but the proportion of AEPs found in the ovules was very low and they were never observed to develop into adventitious embryos. On the other hand, in both H. chrysotrichus and A. acutifolium, selfed pistils do not abort and develop 



Figure 3. Longitudinal sections of ovules and young seeds of Handroanthus serratifolius A-G. with the micropylar end at bottom; H. with micropylar end right. A-B. Sections of young seeds $120 \mathrm{~h}$ after self-pollination. A. Eight celled endosperm with scanty cytosol and pyknotic nuclei; B. Fourteen-celled endosperm with scanty/coagulated cytosol and pycnotic nuclei; C. Adventitious embryo precursor cell (AEP) coming from the hypostase, $72 \mathrm{~h}$ after cross-pollination. This ovule was not fertilized or penetrated by a pollen tube; D. AEP coming from the hypostase into the chalazal chamber of a young two-celled endosperm, $48 \mathrm{~h}$ after self-pollination; E. Sexual proembryo in a seed from fruit at $2 \mathrm{~cm}$ long; F-G. Sexual cordiform embryo in a seed from fruit at $3 \mathrm{~cm}$ long; $\mathbf{H}$. Sexual torpedo embryo in a seed from fruit at $10 \mathrm{~cm}$ long. $\mathrm{CH}$ : chalazal haustorium; $\mathrm{CR}$ : chalazal region; EC: egg cell; ED: endosperm; H: hypostase; MH: micopillar haustorium; MR: micropillar region; PN: polar nuclei; SE: sexual embryo. The arrows indicate the AEP. Scale bars: $20 \mu \mathrm{m}$. 


\section{Post pollination events in a self-sterile hexaploid monoembryonic lineage of Handroanthus serratifolius (Vahl) S. Grose (Bignoniaceae)}

into fruits whose seed are polyembryonic and contains adventitious embryos (Bittencourt \& Morais 2010; Sampaio et al. 2013a; b).

It is possible to speculate that these AEPs may represent a potential for sporophytic apomixis in the monoembryonic individuals of $H$. serratifolius, and that the higher frequency of AEPs in the ovules of $H$. chrysotrichus and A. acutifolium increases the probability of adventitious embryo initiation in these species. Whatever the reason AEPs failure to begin divisions to form adventitious embryos in $H$. serratifolius, their presence in a very limited frequency did not impair the maintenance of LSI in these plants. Moreover, AEP differentiation giving adventitious embryos in apomictic H. serratifolius (Alves et al. 2016), like in H. chrysotrichus (Bittencourt \& Morais 2010) and A. acutifolium (Sampaio et al. 2013a), seem to be essential to avoid self-pistil abortion, and characterize an apomixis-related pseudo self-compatibility (Sampaio et al. 2013a).

This limited potential for sporophytic apomixis in hexaploid monoembryonic individuals of $H$. serratifolius could be a consequence of the allopolyploid condition. It seems that adventitious embryony in sporophytic apomicts is controlled by overexpression of some genes in different cytotypes (Wang et al. 2017). This overexpression should be distinct among monoembryonic and polyembryonic hexaploid $H$. serratifolius and also related to different parental plants for each lineage.

Contrary to our initial expectations, the studied monoembryonic and hexaploid lineage of $H$. serratifolius, the only self-sterile polyploid lineage found in Bignoniaceae, did not show the marked delay in post-pollination events in selfed pistils, as observed in diploid LSI bignoniaceous species. On the other hand, the studied lineage shares with self-fertile, polyembryonic and polyploid lineages/species of the family not only an unexpressive difference between crossed and selfed pistils in the progress of endosperm initiation, but also the capacity to form AEPs at least in some ovules, although being unable to produce apomictic embryos. It is possible that the polyembryonic pseudo selfcompatible and the monoembryonic self-sterile hexaploid populations of $H$. serratifolius are different lineages of allopolyploids with distinct effect of apomixis-related gene expression on AEP formation. Based on the comparisons with the polyploid sporophytic apomictic $H$. chrysotrichus and $A$. acutifolium, the putative interference of the AEPs in the ovules of the hexaploid monoembryonic $H$. serratifolius is not strong enough to avoid selfed pistil abortion, which maintains self-sterility.

\section{Acknowledgements}

This work was supported by CAPES - Coordenação de Aperfeiçoamento Pessoal de Nível Superior - research grant (CAPES/PNPD 23038008068/2010-95). Complementary funding was provided by CNPq and FAPEMIG. We thank the Companhia Energética de Minas Gerais for the help to access treetops; to the Centro Municipal de Estudos e Projetos Educacionais Julieta Diniz and Instituto Federal de Educação, Ciência e Tecnologia do Triângulo Mineiro for permissions to work in these sites; and Mariana Oliveira Duarte for her help in field activities.

\section{References}

Alves MF, Duarte MO, Oliveira PE, Sampaio DS. 2013. Self-sterility in the hexaploid Handroanthus serratifolius (Bignoniaceae), the national flower of Brazil. Acta Botanica Brasilica 27: 714-722.

Alves MF, Duarte MO, Bittencourt NSJr, Oliveira PE, Sampaio DS. 2016. Sporophytic apomixis in polyembryonic Handroanthus serratifolius (Vahl) S. O. Grose (Bignoniaceae) characterizes the species as an agamic polyploidy complex. Plant Systematics and Evolution 302: 651-659.

Ayres M, Ayres Júnior M, Ayres DL, Santos AA. 2007. BioEstat: Aplicações estatísticas nas áreas das Ciências Bio-Médicas. Belém, Sociedade Civil Mamirauá CNPQ.

Barringer BC. 2007. Polyploidy and self-fertilization in flowering plants. American Journal of Botany 94: 1527-1533.

Bittencourt Jr NS. 2017. Evidence for post-zygotic self-incompatibility in Handroanthus impetiginosus (Bignoniaceae). Plant Reproduction 30: 69-79.

Bittencourt Jr NS, Gibbs PE, Semir J. 2003. Histological study of post pollination events in Spathodea campanulata Beauv. (Bignoniaceae), a species with late-acting self-incompatibility. Annals of Botany 91: 827-834

Bittencourt Jr NS, Moraes CIG. 2010. Self-fertility and polyembryony in South American yellow trumpet trees (Handroanthus chrysotrichus and H. ochraceus, Bignoniaceae) a histological study of post-pollination events. Plant Systematics and Evolution 288: 59-76.

Bittencourt Jr NS, Pereira EJ, Sao-Thiago PS, Semir J. 2011. The reproductive biology of Cybistax antisyphilitica (Bignoniaceae), a characteristic tree of the South American savannah-like "Cerrado" vegetation. Flora 206: 872-886.

Bittencourt Jr NS, Semir J. 2004. Pollination biology and breeding system of Zeyheria montana (Bignoniaceae). Plant Systematics and Evolution 247: 241-254.

Bittencourt Jr NS, Semir J. 2005. Late-acting self-incompatibility and other breeding systems in Tabebuia (Bignoniaceae). International Journal of Plant Sciences 166: 493-506.

Bittencourt Jr NS, Semir J. 2006. Floral biology and late-acting selfincompatibility in Jacaranda racemosa (Bignoniaceae). Australian Journal of Botany 54: 315-324.

Collevatti RG, Dornelas MC. 2016. Clues to the evolution of genome size and chromosome number in Tabebuia alliance (Bignoniaceae). Plant Systematics and Evolution 302 :601-607.

Cordeiro JMP, Kaehler M, Souza G, Felix LP. 2017. Karyotype analysis in Bignonieae (Bignoniaceae): chromosome numbers and heterochromatin. Anais da Academia Brasileira de Ciências 89: 2697-2706.

Costa ME, Sampaio DS, Paoli AAS, Leite SCAL. 2004. Poliembrionia e aspectos da embriogênese em Tabebuia ochracea (Cham.) Standley (Bignoniaceae). Revista Brasileira de Botânica 27: 395-406.

Feder N, O' Brien TP. 1968. Plant microtechnique: some principles and new methods. American Journal of Botany 55: 123-142.

Gandolphi G, Bittencourt Jr NS. 2010. Sistema reprodutivo do Ipê-Branco - Tabebuia roseo-alba (Ridley) Sandwith. Acta Botanica Brasilica 24: 840-851.

Gentry AH. 1974. Flowering phenology and diversity in tropical Bignoniaceae. Biotropica 6: 64-68.

Gentry AH. 1992. A synopsis of Bignoniaceae ethnobotany and economic botany. Annals of the Missouri Botanical Garden 79: 53-64.

Gerrits PO, Smid L. 1983. A new less toxic polymerization system for the embedding of soft tissues in glycol methacrylate and subsequent preparing of serial sections. Journal of Microscopy 132: 81-85. 


\section{Mariana Ferreira Alves, Nelson Sabino Bittencourt Júnior, Paulo Eugênio Oliveira and Diana Salles Sampaio}

Gibbs PE. 2014. Late-acting self-incompatibility - the pariah breeding system in flowering plants. New Phytologist 203: 717-34.

Gibbs PE, Bianchi MB. 1993. Post-pollination events in species of Chorisia (Bombacaceae) and Tabebuia (Bignoniaceae) with late-acting selfincompatibility. Botanica Acta 106: 64-71.

Gibbs PE, Bianchi MB. 1999. Does late-acting self-incompatibility (LSI) show family clustering? Two more species of Bignoniaceae with LST: Dolichandra cynanchoides and Tabebuia nodosa. Annals of Botany 84: 449-457.

Gobatto-Rodrigues AA, Stort MN. 1992. Biologia floral e reprodução de Pyrostegia venusta (Ker-Gawl) Miers (Bignoniaceae). Revista Brasileira de Botânica 15: 37-41.

Goldblatt P, Gentry AH. 1979. Cytology of Bignoniaceae. Botaniska Notiser 132: $475-482$.

Govindu HC. 1950. Studies in the embryology of some members of Bignoniaceae. Proceedings of the Indian Academy of Sciences 32: 164-178.

Hörandl E. 2010. The evolution of self-fertility in apomictic plants. Sexual Plant Reproduction 23: 73-86.

Husband B, Ozimec B, Martin SL, Pollock L. 2008. Mating consequences of polyploid evolution in flowering plants: current trends and insights from syntetic polyploids. International Journal of Plant Sciences 169: 195-206.

Joshi AB, Hardas MW. 1956. Ploidy in two bignoniaceous garden climbers. Indian Journal of Genetics and Plant Breeding 16: 57-59.

Levin DA. 2002. The role of chromosomal change in plant evolution. Oxford, Oxford University Press.

Mable BK. 2004. Polyploidy and self-compatibility: is there an association? New Phytologist 162: 803-811.

Mauritzon J. 1935. Etwas uber die embryologie der Bignoniaceae. Botaniska Notiser 1935: 60-77.

McDowell EM, Trump B. 1976. Histological fixatives for diagnostic light and electron microscopy. Archives of Pathology \& Laboratory Medicine 100: 517-527.

Mendes-Rodrigues C, Sampaio DS, Costa ME, et al. 2012. Polyembryony increases embryo and seedling mortality but also enhances seed individual survival in Handroanthus species (Bignoniaceae). Flora 207: 264-274.

Mendes-Rodrigues C, Marinho RC, Balao F, et al. 2019. Reproductive diversity, polyploidy, and geographical parthenogenesis in two Eriotheca (Malvaceae) species from Brazilian Cerrado. Perspectives in Plant Ecology, Evolution and Systematics 36: 1-12.
Nettancourt D. 1997. Incompatibility systems in angiosperms. - Sexual Plant Reproduction 10: 185-199.

Oliveira PE, Gibbs PE, Barbosa AA, Talavera S. 1992. Contrasting breeding systems in two Eriotheca (Bombacaceae) species of the Brazilian cerrados. Plant Systematics and Evolution 197: 207-219.

Pannell JR, Obbard DJ, Buggs RJA. 2004. Polypolidy and the sexual system: what can we learn from Mercurialis annua? Biological Journal of the Linnean Society 82: 547-560.

Piazzano M, Peñas ML, Chiarini F, Bernadello G. 2015. Karyotypes and DNA content in Bignoniaceae. Caryologia 68: 175-183.

Ramsey J, Schemske DW. 1998. Pathways, mechanisms, and rates of polyploid formation in flowering plants. Annual Review of Ecology and Systematics 29: 467-501.

Sage TL, Bertin RJ, Williams EG. 1994. Ovarian and other late-acting selfincompatibility systems. In: Willianms EG, Clarke AE, Knox RB. (eds.) Genetic control of self-incompatibility and reproductive development in flowering plants. Dordrecht, Kluwer Academic. p. 116-140.

Sampaio DS. 2010. Biologia reprodutiva de espécies de Bignoniaceae ocorrentes no Cerrado e variações no sistema de autoincompatibilidade. PhD Thesis, Universidade Federal de Uberlândia, Uberlândia.

Sampaio DS, Bittencourt Jr NS, Oliveira PE. 2013a. Mating in the pseudogamic apomictic Anemopaegma acutifolium DC: another case of pseudo-self-compatibility in Bignoniaceae? Plant Biology 15: 919-924.

Sampaio DS, Bittencourt Jr NS, Oliveira PE. 2013b. Sporophytic apomixis in polyploid Anemopaegma species (Bignoniaceae) from Central Brazil. Botanical Journal of the Linnean Society 173: 77-91.

Sampaio DS, Costa ME, Paoli AAS. 2007. Ontogenia da semente de Tabebuia ochracea (Cham.) Standl. (Bignoniaceae). Revista Brasileira de Botânica 30: 289-302.

Seavey SR, Bawa KS. 1986. Late-acting self-incompatibility in angiosperms. The Botanical Review 52: 195-219.

Simmonds NW. 1954. Chromosome behaviour in some tropical plants. Heredity 8: 139-146.

Soltis PS, Soltis DE. 2016. Ancient WGD events as drivers of key innovations in angiosperms. Current Opinion in Plant Biology 30: 159-165.

Wang X, Xu Y, Zhang S, et al. 2017. Genomic analyses of primitive, wild and cultivated Citrus provide insights into asexual reproduction. Nature Genetics 49: 765-772.

Whitton J, Sears CJ, Baack EJ, Otto SP 2008. The dynamic nature of apomixis in the angiosperms. International Journal of Plant Sciences 169: 169-182. 